and was awarded the Symons Gold Medal of the Royal Meteorological Society in 1938. Since then he has been engaged in investigations of the relationship between changes in weather and the humidity and ozone content of the stratosphere. During and since the War he has been investigating the formation of ice in the atmosphere, a problem of great importance to pilots from the point of view of condensation trails. In his lecture, which follows the presentation, Dr. Dobson will recall some personal memories of Dr. Chree, and will then speak on the subjects mentioned above.

\section{British Society for the Promotion of Vegetable Research}

A statron for fesearch in vegetable production in Great Britain has now been established under a governing bod constituted as a company limited by guarantee and without a share capital, with the title of the Britigh Society for the Promotion of Vegetable Research. For the funds for its work, the Society will at the outset depend on grants from the Ministry of Agr/culture (for stations in Scotland, from the Depaytment of Agriculture for Scotland). The Agricultural Research Council will exercise general scientific guidance and will supervise the work and staff of the Society. The members of the governing body-twenty-three in number-include nominees of the Ministry of Agriculture and the Department of Agriculture for Scotland, the Department of Scientific and Industrial Research, various learned societies, universities and institutions concerned with horticulture, vegetable producers large and small (through the National Farmers' Union and that of Scotland, and the National Allotments and Gardens Society) and trade interests. The chairman of the Society is Prof. F. T. Brooks, of the University of Cambridge, and the director of the research station is Dr. James Philp (see Nature, 161, 715; 1948). The headquarters research station will be at Wellesbourne, Warwickshire (where the registered office of the Society will also be situated), and consists of 280 acres of deep sandy loam over gravel or keuper clay; the land is being purchased by the Ministry of Agriculture and will be leased to the Society. The site is admirably suited to research on vegetables; but some time must necessarily elapse before buildings and equipment can be provided, staff engaged and the farm generally developed for research purposes. The Ministry is also leasing to the Society 150 acres of land which it owns at Paglesham, Essex, for a substation primarily to be used for the multiplication of stocks of seed of vegetables bred at the main station or elsewhere. A second sub-station is the former Horticultural Research Station at Cambridge, which has been taken over from the University of Cambridge, and the staff of which will continue to work there until they can be transferred to the headquarteys station.

\section{Indian Phytopathology}

WITH the rapje advances made in mycology and plant pathos throughout India during the past quarter of a fintury (since the late Sir Edwin John Butler wog appointed the first Imperial mycologist at the Pusa Agficultural Research Institute) the time was fully ripe for the publication of a journal devoted to $\widehat{\Theta}$ interests of the Indian Phytopathological Society. In introducing the first number of the journal, entitled Indian Phytopathology, the president of the Council, Mr. J. F. Dastur, hopes that a still closer association and relations will be effected among members of the Society and other scientific workers, both in India and abroad. The interests of the Society extend over six areas or zones, namely, the northern Delhi, eastern, western, central and southern, and are watched over by Dr. Pushkarnath, Dr. Vasudeva, Dr. Mehta, Dr. Uppal, Mr. Kulkarni and Mr. K. M. Thomas respectively.

The editorial board consists of the well-known pathologists Dr. B. B. Mundkur (editor-in-chief [see p. 680 of this issue]), Dr. S. R. Bose, Dr. M. K. Patel, Dr. R. K. Saksena and Dr. R. S. Vasudeva. The first number of the journal, consisting of ninety-six pages, is devoted to valuable contributions of high standard on a wide range of topics. The journal is beautifully printed and illustrated on good quality paper. The annual subscription is Rs. 14 (one guinea) post paid. There will be, for the present, two issues in a year, comprising about 250 pages; but the number of pages and issues per annum will be gradually increased. Subscriptions should be sent to the Secretary-Treasurer, Indian Phytopathological Society, Pusa Buildings, New Delhi.

\section{World Crops: A Nely Monthly Journal $\quad$ H6 \\ SINCE the Second Vorld War, attention has been} increasingly focosed $0 n$ the international aspect of agriculturd 1 sroblems, and the appearance of a new month journal, World Crops, published by Leonard All Itd., under the editorship of Sir Harold Tempary, is appropriate. The scope of the journal is wide, embracing the cultivation, protection, storage and handling of many essential crops, and their processing for food, fodder and industrial products. Its purpose is to describe, in not too technical language, the results of research, and to discuss such current topics and problems as will interest both the grower and manufacturer as well as the administrator and scientific worker. Among the outstanding world agricultural problems of to-day is the necessity for increasing the production of rice and vegetable oils and to find means for controlling the disease that threatens the cocoa industry. Authoritative articles dealing with these subjects appear in the first number, issued in September 1949. The prospects for the extension of tobacco production in East and Central Africa are also discussed, and an account is given of the project of the British Overseas Corporation for the growing of sorghum and the setting up of piggeries in Queensland, Australia. Items of general interest include an article on agricultural education and reports of recent important conferences and meetings. Good illustrations are evidently intended to be a feature of the new journal ; the subscription rates are, one year $25 s$, two years $40 s$, and three years $50 s$.

\section{Vegetation Maps of Switzerland H/b}

THE Phytogeographical Committee of the Swiss Society of Jatural Sciences has planned, and Dr. Emil Schmid prepared, a Yegetation map of Switzerlant to N scale of 1390,00 or about three miles to thy inch. The mps is iss ed in four folded sheets of which two, Nos 1 and 4 of the series, have so far been received. No. 1 covers the north-west sector including Bern, Neuchâtel, Basel and Aarau, and No. 4 the south-east sector or the Gotthard-Tessin-Graubünden area. Eleven primary types of vegetation are recognized. These are shown in different colours, with the chief associations in each type differentiated by symbols indicating the dominant species; the 
extents of arable cultivation and grassland within each primary vegetation type are also indicated. The associations shown are for the most part forest types, the twenty-two symbols representing dominants all referring to trees and shrubs. The maps are thus particularly valuable as showing at a glance the types and detailed distributions of woodlands and their relation to topographical features and geographical location. The utility of these finely printed maps to botanical visitors will be considerable, though placenames are not easy to decipher beneath the superimposed colours and symbols. The legends and keys are given in French and German, and each map measures $37 \mathrm{in.} \mathrm{by} 26 \frac{1}{2} \mathrm{in}$. They are printed on stiff paper by Kummerly and Frey of Bern and are obtainable from Hans Huber of Bern at a cost of 12 Swigs francs each.

\section{Ancient Fishing on the River Severn}

THE interest in folk museums is growing throughout Great Britain. Th ere those who would like to se ingmensp buas set aside for folk studies on a nolifnal seall on the Scandinavian plan, whereas others are content with more regional establishments, even down to a county basis ; but no folk museum of any kind will be of the slightest value unless its collections provoke study and subsequent publication. It is for this reason that a modest little work, "Guide to the Severn Fishery Collections", by J. Neufville Taylor, which has been published by the City of Gloucester Folk Museum, is to be commended, and it is to be hoped there will be many more like it. The various methods used on the River Severn to catch the difierent fish required will also be of interest to fishermen, even to those who despise all methods except that of the rod, fly and line.

\section{The European Bison}

In recent yedrs, the Society for the Preservation of the Figupla of the Empire has taken keen interest in the forts made by the International Society for the Preservation of the Wisent [European bison] to save this remarkable relative and possibly forbear of the American bison from extinction. Its ultimate survival is still open to doubt and, in the July issue of the Journal of the Society for the Preservation of the Fauna of the Empire, is assembled the latest information procurable on the status of the species. Frof. Jan Zabinski and Miss Erna Mohr contribute authoritative articles from difierent points of view, and these are prefaced by extracts from a recent paper of Vir. Richard Glover's which both summarizes the known history of the wisent and deals with its contrasts to and similarities with the American bison. If suitable action is taken, there seems to be reasonable hope that the wisent may survive under protection in the right conditions of forest space to bring its numbers up to those which existyd before the First World War.

\section{The Mo!luscan Stomach}

IN continuation of hionstudies on the alimentary canal of Mplusca, Pff. A. Graham has described the stomach of typiffl lamellibranchs and prosobranch getstrepgis, Qiscussed the functions and howategies of he parts and compared them with those of Polyplacophora and Cephalopoda ("The Molluscan Stomach", by Alastair Graham. Trans. Roy. Soc. Edin., 61, Part 3, No. 27 ; 1949). The molluscs considered range from the ciliaryfeeding microphagous lamellibranchs to the browsing macrophagous gastropods; but only to the more primitive members of the latter class, which exhibit, at least in the trochids, a close resemblance to the lamellibranch type of stomach, with its style sac, major and minor typhlosoles, cecum, grooved sorting area and gastric shield. A simplification of this structure is to be expected in carnivorous gastropods, and does, in fact; occur. One effect of torsion on the primitive form of the stomach is the displacement of the cesophagus from an anterior to a posterior position, so that eventually, in tectibranchs and pulmonates, the cesophageal and intestinal openings are adjacent to one another, and as a result the stomach itself becomes a cæcum receiving the ducts of the digestive gland. The stomach of Patella is peculiar in that it is small, ill-defined and devoid of a cæcum or gastric shield, but it possesses two typhlosoles. The paper is illustrated by twenty-three figures of outstanding merit, prepared by a skilled use of scraper board combined with mechanical stippling.

\section{The Backward Agfltw}

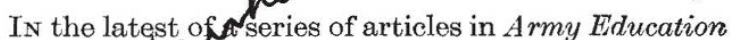
(23, No. 2 , the 1949), Dr. W. D. Wall describes the case studies the has made with backward men. His inguir es with adults are supported by investigations wict have been made with groups of backward children in schools and show that the majority of the educationally retarded are below the general level of the population in intelligence; any group of poor readers is likely to contain between a half and twothirds of men whose level of intelligence is subnormal. On the other hand, there are many nearilliterates whose mental level is nearly normal or even supernormal. Some of these often have difficulty in distinguishing the shapes of similar letters like $b$ and $d, m$ and $n, p$ and $q$. In other cases there is a tendency to reversals, either of single letters or of words, showing that the habit of attacking a word from left to right is not established. Some backward adults of average intelligence have marked difficulties in recalling material presented aurally or visually, or in synthesizing into whole words syllables which can visually or auditorily be discriminated quite well. A third class of defects is physiological, and, in a group of a hundred backward readers studied by Wall, defects of hearing and vision were nearly twice as frequent as among a group of normal readers of otherwise comparable background. Speech defects-stammering, lisping and marked hesitations accompanied by disturbance of breathing-and lefthandedness or a tendency towards it also seem to operate as handicaps in learning. The factor which, apart from intelligence, is of greatest significance in leading to backwardness is that of personal adjustment. In Wall's inquiries nearly two-thirds of the men showed that they were not adjusting themselves to the demands of even a relatively simple existence. It is, however, difficult to estimate how far emotional disturbances during and after school life inhibit learning and how far educational failure contributes to adult maladjustment.

\section{Measuring Proforictivity}

THE 1848 49 Winter Proceedings of the British Institute of Management have been presented as a report. The fourth meeting was addressed by Sir Ewart Siptth and Dr. R. Beeching who, in a joint paper, discussed the means of measuring the effectiveness of the productive unit. After defining the meaning of 